\title{
ОСОБЛИВОСТІ МЕХАНІЗМУ ІНДИВІДУАЛЬНӦ̈ ЗЛОЧИННОӤ ПОВЕДІНКИ, ПЕРЕДБАЧЕНОЇ СТ. 377 КК УКРАЇНИ: КРИМІНОЛОГІЧНИЙ АНАЛІЗ
}

\author{
МАР'СНКО Лариса Михайлівна - аспірантка Харківського національного \\ університету внутрішніх справ
}

УДК 343.9

DOI 10.32782/LAW.UA.2021.2.18

Статья посвящена криминологическому анализу механизма совершения угроз и насилия в отношении судей (ст. 377 УК Украинъ ). Въяяленъ, описанъ и объясненъ особенности стадии актуализации потребности, бормирования мотива, принятия решения о совершении этого преступления, его реализации, посткриминального поведения. Отдельно исследовано влияние криминогенной ситуачии на развертьлвание криминальной активности, предусмотренной ст. 377 УК Украинъ, в результате чего вълелено и охарактеризовано пять их видов по критериям источников их происхождения и содержания.

Ключевъе слова: угроза, насилие, судья, преступление, механизм, мотив, ситуация.

\section{Постановка проблеми}

Проблеми належної охорони правосуддя від суспільно небезпечних посягань - одні $з$ ключових у справі розбудови демократичної, правової держави Україна. Судова влада за визначенням несе на собі обтяження функціонального балансу та забезпечення соціальної справедливості і, таким чином, легітимізації держави як такої. Тож від правильного функціонування суду в значній мірі залежить стійкість соціально солідарних станів, зміцнення суспільної моралі і прогресивний соціальний розвиток у цілому. Однак істотним фактором, що перешкоджає досягненню цієї стабільності і стійкості, легітимності апарату держави, фальсифікує його засади, є віднос- но поширені кримінальні практики, передбачені ст. 377 КК України. Вчинення погроз або насильства щодо суддів значно знижує ефективність судочинства, ставить під загрозу можливість нормальної реалізації прав громадян на справедливий суд. Успішна ж протидія погрозам або насильству щодо суддів вимагає оперування відповідною науковою інформацією про їх стан, детермінаційну природу. Значущим компонентом подібної інформаційної моделі є механізм індивідуальної злочинної поведінки.

Різним аспектам протидії погрозам та насильству щодо суддів приділялася увага в працях М. І. Бажанова, О. М. Бандурки, А. В. Галахової, В. В. Голіни, О. М. Джужи, О. О. Дудорова, В. С. Зеленецького, О. Г. Кальман, О. М. Костенка, С. С. Мiрошниченка, В. І. Осадчого, $\lambda$. М. Палюха, Є. $\curlywedge$. Стрельцова та інших дослідників. Водночас механізм індивідуальної злочинної поведінки означеного штибу й досі не був предметом дослідження, не розроблений на науковому рівні, що й зумовлює актуальність теми статті.

Метою статті $\epsilon$ виявлення, науковий опис та пояснення особливостей основних складових механізму вчинення погроз або насильства щодо суддів в Україні.

Виклад основного матеріалу

У науці кримінології під механізмом індивідуальної злочинної поведінки прийнято 
розуміти модель взаємодії особистості і зовнішнього середовища, що реалізується у вчиненні конкретного кримінального правопорушення. Його основними елементами здебільшого вважають: а) умови формування особистості; б) мотивація; в) конкретна життєва ситуація; г) рішення про вчинення кримінального правопорушення; д) сам процес його вчинення $[1$, с. $411 ; 2$, с. $16 ; 3$, с. 107 та ін.]. Дотримуючись такого бачення аналізованого феномену, а також грунтуючись на аналіз матеріалів 110 кримінальних проваджень, 43 вироків у провадженнях (кримінальних справах) про злочини, передбачені ст. 377 КК України, а також на результатах опитування 205 суддів місцевих судів загальної юрисдикції, 42 повідомлення у засобах масової інформації, 239 рішень Вищої ради правосуддя про вжиття заходів щодо забезпечення незалежності суддів та авторитету правосуддя за повідомленнями суддів, можемо виділити такі особливості механізму вчинення погроз або насильства щодо суддів.

I. Актуалізачія потреби ц̌ бормування мотиву на вчинення погрози або насильства щодо суддів відбувається під впливом складових суспільних відносин, що виникають, розвиваються у зв'язку зі здійсненням правосуддя, безпосереднє (як учасника) або опосередковане (як іншого суб'єкта, зацікавленого у результатах судового розгляду) залученням особи до орбіти цих відносин. У результаті формуються такі основні мотиви:

1. Мотив гарантування безпеки, пов'язаний зі спонуканням судді до прийняття певного рішення у справі. Типовим є випадок, коли 3 квітня 2019 року близько 11:00 на мобільний телефон судді Дніпропетровського районного суду Дніпропетровської області надійшли sms-повідомлення з використанням ненормативної лексики та погрозами здійснення фізичної розправи стосовно неї та іiі сім'ї, якщо рішення у справі не буде ухвалене на користь певних учасників процесу [4, с. 129].

2. Мотив самоактуалізацї (самоствердження), який змістовно тяжіє до так званого хуліганського мотиву, виражає устремління особи до домінування над встановленими у суспільстві правовими порядками, зокрема через кримінально-протиправний, суспільно небезпечний вплив на представника судо- вої гілки влади у зв'язку зі здійсненням ним правосуддя. Формування такого мотиву безпосередньо пов'язане $з$ обстановкою можливого подальшого вчинення злочину, себто наявності сторонніх спостерігачів, присутніх, наприклад, у залі судових засідань. Керовані такими мотивами особи злочинців належать до демонстративного кримінологічну типу.

3. Мотив помсти. Відповідно до повідомлення судді Запорізького районного суду Запорізької області, що надійшло до Вищої ради правосуддя 21.05.2019 р., відразу після судового засідання обвинувачений у кримінальному провадженні, перебуваючи під вартою, у залі судового засідання у присутності прокурора Запорізької місцевої прокуратури № 2, захисника, секретарів судових засідань, конвоїрів, почав висловлювати погрози застосування щодо головуючого судді насильства та вбивства після свого звільнення з-під варти [4, с. 125]. Звісно, при наближеному аналізі така спонука, як помста, виявляе якщо не цілковите злиття, то, принаймні, наявність дотичних граней із безпековими та самоактуалізаційними мотивами. Але особливий, своєрідний «каральний» функціонал помсти дозволяє все ж виділити відповідний мотив як гносеологічно окрему категорію.

\section{II. Прийняття рішення про вчинен-} ня злочину відбувається за неоднакових як об'єктивних, так і суб'єктивних умов.У зв'язку з чим не зайвим буде відзначити те, що за характером мотиваційного процесу погрози або насильство щодо суддів здебільшого є вольовими кримінальними правопорушеннями. Це означає, що приблизно у 70 \% випадків безпосередньому акту погрози передує стадія прийняття рішення про вчинення злочину, для якої характерне хоча й нетривале, все ж обдумування деталей, цілей його вчинення, аналіз обстановки, обрання певних способів, підбір дискурсивних інструментів. Однак, поряд з цим, лише кожен десятий 3 цих злочинів характеризується заздалегідь обдуманим умислом. У решті випадків - він такий, що раптово виникає. Сама ж фаза прийняття рішення $\epsilon$ не надто тривалою. У $60 \%$ випадків рішення при вчинення злочину, передбаченого ст. 377 КК України, приймається безпосередньо в залі судових засідань, у $30 \%$ - в інших приміщеннях суду (коридорі, 


\section{Кримінальне право, кримінальний процес та криміналістика}

сходовому марші, службовому кабінеті судді і т. п.). Щодо кожного десятого злочину рішення приймається поза будівлею суду (за місцем проживання, відбування покарання, на вулиці тощо).

Водночас стадія прийняття рішення про вчинення злочину майже відсутня (максимально стиснена у часі й змісті інтелектуального процесу) у 30 \% випадків, пов'язаних із висловленням (іншим чином вираженням) погроз на адресу судді. За актуалізацією потреби й формуванням мотиву майже одразу, миттєво минаючи етап прийняття рішення про вчинення злочину, слідує фаза активних дій щодо приведення імпульсу у дію. Мотиваційний процес цих кримінальних правопорушень характеризується імпульсивністю, великим значенням сильного душевного хвилювання, екзистенціальним сплеском, якому відповідає дуже високий рівень нервового й емоційного збудження.

Щодо фактичного нанесення судді або їх близьким родичам тілесних ушкоджень у зв’язку з їх діяльністю, пов'язаною із здійсненням правосуддя, то ці кримінальні правопорушення приблизно у $95 \%$ випадків є вольовими; лише у $5 \%$ має місце імпульсивна поведінка.

III. Реалізація прийнятого рішення є центральним елементом всього механізму індивідуальної злочинної поведінки. Здебільшого погрози висловлюються усно (94\%), до оголошення рішення суду (76\%). Остання обставина свідчить про превалювання в структурі погроз або насильства щодо судді тих випадків, що мають на меті вплинути на прийняття рішень. Проте у $23 \%$ має місце висловлення наміру про помсту за професійну діяльність судді.

У більшості своїй погрози - це дії, висловлені під час або одразу після проголошення вироку у кримінальному провадженні під час судового засідання, у залі суду, перебуваючи в місцях, відведених для осіб, щодо яких обрано запобіжний захід у виді тримання під вартою. Вони висловлюються усно, особисто, безпосередньо (80 \% випадків). У той же час слідча і судова практика фіксує й інші способи висловлення погроз насильством судді:

а) телеббоном усно безпосереднъо судді або іншому працівнику суду (5-7 \% випадків). Наприклад,
13.03.2020 р. близько 14 год. 30 хв. помічнику судді М. на службовий телефон приймальні заступника голови Московського районного суду міста Харкова Д. А. Крівцова надійшов дзвінок від невстановленої особи, яка відмовилась себе назвати та, використовуючи в розмові ненормативну лексику, вимагала з'єднати іiі із суддею Д. А. Крівцовим, а після отримання відмови почала висловлювати погрози вбивством та застосуванням фізичного насильства стосовно вказаного судді [5]. Як можна бачити, у цьому випадку взагалі не принципово було, якому саме судді висловлюється погроза. Провідною спонукою було домінування над інституцією в особі фактично будь-якого іiі працівника, демонстрація зневаги та власної зверхності;

б) через смс-повідомлення й повідомлення на Інтерент-сторінках (боруми, чати, дописи й коментарі під постами тощо - 5 \%). Так, суддя Жовтневого районного суду міста Кривого Рогу Дніпропетровської області повідомив, що 11.01.2017 р. невідомий чоловік у дворі житлового будинку під вікнами квартири судді вчинив підпал автомобіля, який належить цивільній дружині судді. Суддя додав до повідомлення роздруківки 3 інтернет-сайтів із коментарями щодо фізичної розправи над суддею та членами його родини, у тому числі із закликами «спалить вместе с машиной», які були розміщені за два дні до підпалу вказаного автомобіля. 14.01.2017 р. на особистий мобільний номер телефону судді надійшли sms - повідомлення з образами на адресу судді та погрозами щодо продовження протиправних дій, спрямованих на розправу над суддею та членами його родини [4, с. 126];

в) електронною поштою (3-5 \%), поштовою кореспонденцією, через канцелярію суду або на домашню адресу судді (2 \%). Так, 28.06.2012 р. гр.-н К., переслідуючи прямий умисел, спрямований на порушення особистої безпеки судді Джанкойського міськрайонного суду АР Крим гр-ки М., $з$ метою помсти, у зв’язку 3 винесенням 27.10 .2011 р. обвинувального вироку цим суддею стосовно нього, за яким він засуджений до 7 років позбавлення волі 3 конфіскацією майна, перебуваючи в приміщенні гуртожитку для засуджених Петрівської виправної колонії № 49 У ДПтСУ в Кіровоградській обл., власноручно написав листа, 
у якому виклав погрози вбивством, фізичною розправою судді членів їі сім’і. Вказаний лист вклав до конверта та відправив поштою, кинувши його до поштової скриньки на території Петрівської ВК № 49. Отримавши його 11.07.2012 р., суддя Джанкойського міськрайонного суду АР Крим гр-ка М ознайомилась зі змістом та сприйняла погрози як реальні [6]. Як можна пересвідчитись, доступність засобів зв'язку, а також недостатній контроль за ïх використанням 3 боку засуджених до позбавлення волі є факторами, які значно спрощують можливість вчинення кримінальних правопорушень, передбачених ст. 377 КК України, навіть особами, які відбуваються покарання у кримінально-виконавчих установках закритого типу. Окрім іншого, викладені випадки наочно засвідчують важливість забезпечення належного захисту персональних даних суддів задля мінімізації можливості вчинення означених злочинів засобами поштової кореспонденції, а також телефонного зв’язку, електронної комунікації;

2) комбінованими засобами та способами, 3 використанням sms-повідомлень, повідомлень у месенджерах та особистих погроз (2-3\%);

д) через конклюдентні дї, щзо носять характер погроз застосування насильства (поодинокі випадки). Наприклад, 01.10.2020 р. о 03 год. 35 хв. стався вибух невідомого предмета у внутрішньому дворі Вищого антикорупційного суду за адресою: проспект Перемоги, 41, місто Київ. Внаслідок вибуху пошкоджено фасад будівлі суду. Голова суду О. В. Танасевич вказує, що Вищий антикорупційний суд розцінює цю подію як факт втручання у діяльність суду щодо здійснення правосуддя у спосіб, небезпечний для життя і здоров'я, спрямований на перешкоджання виконанню суддями службових обов'язків [7].

у переважній більшості випадків $(90,8 \%)$ фізичне насильство щодо судді застосовується шляхом завдання ударів ногами й руками по різних частинах тіла. Водночас приблизно кожен десятий напад на суддю здійснюється 3 використанням предметів, спеціально пристосованих або заздалегідь підготовлених для нанесення тілесних ушкоджень: бейсбольні бити, дерев’яні палки, металева арматура і т. п.- у поодиноких випадках застосовуються технічні пристрої травмуючої дії (електрошокер), або хімічні речовини - сльозогінний газ, кислоти, луг. При цьому зустрічається й застосування комбінації заходів і методів фізичного впливу.

Місце нанесення судді тілесних ушкоджень локалізується здебільшого (у 40 \% випадків) на прилеглій до помешкання судді території (вхід до під’їду, виїзд з гаражу). Приблизно 30 \% - приміщення суду або прилегла до суду територія. Ще стільки ж, тобто 30 \%, - інші місця (парки, вулиці міста тощо).

Окремо слід наголосити на тому, що проведене нами дослідження виявило наявність прогалини у кримінально-правовому захисті правосуддя і суддів від деяких насильницьких видів втручання. Йдеться, зокрема, про такий вид, як незаконне позбавлення волі у формі перешкоджання судді вільно залишити місце, у якому вона більше не бажає знаходитись, зокрема зали судових засідань після оголошення про перерву у судовому розгляді тощо. На практиці ці випадки є не вельми поширеними, однак з 2014 р. регулярно фіксуються, пов'язані із розглядом судами справ так званих «активістів». Наприклад, це наочно видно на відеоматеріалі, розміщеному на Інтернет-ресурсі «Відкритий суд» [8]. Тож вважаємо, кримінальний закон має бути відповідним чином доповнений.

IV. Криміногенні ситуацї. Ведучи мову про криміногенні ситуації, що мають місце при вчиненні погроз або насильства щодо суддів, можемо виділити такі їх різновиди:

1) за джерелом походження:

- створені самим злочинцем, зокрема - доведення себе до стану алкогольного сп'яніння (5\% випадків);

- створені жертвою, тобто суддею (10\% випадків), а саме: а) нетактовність, інша неетична поведінка судді (формалізм у розгляді питань, нехтування особистим часом учасників процесу, зверхність, зухвалість у спілкуванні $з$ ними тощо); б) безпідставна відмова у задоволенні клопотань, відмова від задоволення клопотання у відводі судді за наявності до того підстав; в) предикатне корупційне правопорушення з боку судді у зв'язку зі справою, стороною в якій є особа, яка вчиняє погрозу або насильство; 


\section{Кримінальне право, кримінальний процес та криміналістика}

- створені третіми особами чи інфраструктурними особливостями (10\%): а) працівниками правоохоронних органів, зокрема органів дізнання і досудового слідства, які не забезпечили дотримання всіх вимог процесуального законодавства щодо об'єктивності, повноти розслідування, чинили неправомірний тиск на учасників кримінального провадження і т. п.; б) неетичною, неправомірною поведінкою представників сторони захисту у кримінальному провадженні, інших учасників проваджень; в) безвідповідальністю службових осіб служби судової охорони, які неналежним чином забезпечили охорону приміщень суду, допускають можливість пронесення заборонених предметів, не дотримують вимог тактики охорони судді від нападу під час судового засідання або одразу після нього; г) відсутність відеофіксації судового засідання, а також усього проміжку часу перебування потенційного злочинця у залі судових засідань.

2) за змістом: а) конфліктні криміногенні ситуації (10 \% випадків), що виражають міжособистісний конфлікт злочинця та іншого учасників судового процесу, в інтересах якого приймається законне рішення. Негативне відношення злочинця до іншої сторони конфлікту проєктується на суддю, діяльність якого суб'єктивно афіліюється з несправедливістю, упередженістю; б) проблемні криміногенні ситуації (100\%), що виражають протиріччя між бажаним для особи результатом судового розгляду та вимогами закону, якими керується суддя.

Зауважимо, що в одиничному акті злочинної поведінки можуть сполучатися різні криміногенні ситуації, що значно підвищує імовірність прийняття остаточного рішення про погрозу або насильство щодо судді, інтенсивність, емоційність розгортання механізму криміногенези, тяжкість заподіюваних тілесних ушкоджень. У зв’язку з цим нейтралізація криміногенних ситуацій має стати окремим напрямом у запобіганні поширенню погроз або насильства щодо суддів.

V. Посткримінальна поведінка, як аргументувалося нами вище, має важливе значення для вторинної чи подальшої криміналізації особистості. Здійснене нами дослідження дозволяє виділити такі типи посткримінальної поведінки, притаманної для осіб, які вчинили погрозу або насильство щодо суддів:

1. Активно-антикриміногенна поведінка, пов'язана 3 щирим каяттям, усвідомленням хибності й неприйнятності намірів, дій, пов'язаних із висловленою (іншим чином виражено) погрозою або застосуванням насильства щодо судді, намаганням компенсувати заподіяну шкоду. Ця поведінка $є$ найбільш сприятливою для виправлення особи та, водночас, такою, що зустрічається не вельми часто. Відповідно до зібраних нами експертних оцінок серед суддів і працівників установ виконання покарань закритого типу частка осіб 3 досліджуваної нами категорії, що демонструють подібну поведінку, не перевищує 5 $\%$.

2. Послідовно-криміногенна поведінка (зустрічається приблизно у 20 \% випадків), що має місце у випадку розгортання системи злочинної діяльності з боку так званого реального кримінологічного типу злочинця, коли висловлена погроза підкріплюється твердим реальним наміром втілити їі у життя за сприятливої для цього обстановки (після звільнення з місць позбавлення волі, у зручному місці і у зручний час тощо). Така поведінка характеризується: а) активною дією механізмів психологічного захисту, утриманням орієнтації на самовиправдання, перекладання вини на інших, у тому числі й на жертву, легітимізацією попередньої та майбутньої кримінальної поведінки; б) збереження агресивного потенціалу й високої тривожності особистості, що має значення фонової детермінації (за механізмом прояву замісної агресії) для інших, супутніх кримінальних правопорушень, безпосередньо не пов'язаних з генезою злочину, передбаченого ст. 377 КК України.

Особи, які демонструють послідовно-криміногенну посткримінальну поведінку, характеризуються підвищеною схильністю до насильницьких злочинів під час відбування покарання, що важливо враховувати і при прогнозуванні ризику рецидиву кримінальних правопорушень (повторного вчинення кримінального правопорушення - у термінології Закону України «Про пробацію» (ч. 3 ст. 9) [9]) у процесі досудової пробації, і при складанні й реалізації індивідуальних програм ресоціалізації (якщо, звісна річ, мова 
йде про відбування покарання у виді позбавлення волі) або ж при виконанні покарань, не пов’язаних $з$ позбавленням волі. Саме на цій стадії у вказаній ії змістовній варіації відбувається планування вчинення насильства щодо судді, підшукування співучасників, змова на вчинення кримінального правопорушення, що може бути реалізована навіть і під час відбування особою покарання у виді позбавлення волі, шляхом виконання злочину іншими особами чи то за винагороду, чи то за переконанням.

3. Нейтрально-нігілістична поведінка, для якої не $\epsilon$ характерним щире каяття та, водночас, відсутність установки на неодмінне втілення висловлених раніше судді погроз у життя. Найчастіше 3 часом, зі зниженням ступеня емоційної напруженості, екзистенціального сплеску відбувається і відмова від наміру здійснити фізичне насильство щодо судді, його близьких родичів, пошкодити або знищити їх майно. Цей тип посткримінальної поведінки найбільш поширений та зустрічається приблизно у $75 \%$ випадків.

\section{Висновки}

Підсумовуючи, зауважимо, що в результаті проведеного дослідження удосконалено наукове знання про особливості механізму індивідуальної злочинної поведінки, передбаченої ст. 377 КК України, для якої властиві мотиви забезпечення безпеки, самоствердження і помсти; здебільшого погрози висловлюються усно (94\%), особисто, безпосередньо (80 \%), до оголошення рішення суду (76\%) і мету вплинути на прийняття суддею рішення, у $23 \%$ - помсти за професійну діяльність судді; фізичне насильство у виді легких тілесних ушкоджень $(87,5 \%)$ у більшості випадків застосовується на прилеглій до помешкання судді території (40 \%) або в приміщенні суду (30 \%) шляхом нанесення ударів руками і ногами; досліджено посткримінальну поведінку, виділено три ії типи: активно-антикриміногенну, послідовно-криміногенну, нейтрально-нігілістичну. Набуло подальшого розвитку наукове уявлення про характер і значення криміногенних ситуацій у механізмі вчинення погроз або насильства щодо судді, народного засідателя, присяжного, у результаті чого виділено, описано та пояснено п’ять їх видів за критеріями джерела їх походження та змісту. Перспективним напрямом подальших досліджень видається аналіз віктимної поведінки суддів як складової криміногенної ситуації та більш широкого комплексу віктимогенних факторів кримінальних правопорушень, передбаченихст. 377 КК України.

\section{Лiтература}

1. Гладкова E. О. Механізм злочинної поведінки // Українська кримінологічна енциклопедія / за заг. ред. В. В. Чернєя, В. В. Сокуренка ; упоряд. О. М. Джужа, О. М. Аитвинов. - Харків - Київ : Харк. нац. ун-т внутр. справ ; Нац. акад. внутр. справ, Кримін. асоц. України, Золота миля, 2017. С. 411-414.

2. Щербакова А. К., Аитвинов О. М. Механізм індивідуальної злочинної поведінки особи, яка вчиняє бандитизм: характеристика та протидія : монографія / За заг. ред. О. М. Аитвинова. Х. : Панов, 2015. 236 с.

3. Бандурка О. М., Литвинов О. М. Механізм злочинної поведінки. Вісник Кримінологічної асоціациї Украӥни. 2016. № 3 (14).C. 109-119.

4. Щорічна доповідь про стан забезпечення незалежності суддів в Україні за 2019 p. / Вища рада правосуддя. К., 2020. URL: https://hcj.gov.ua/sites/default/files/field/file/ shchorichna_dopovid_za_2019_rik.pdf (дата звернення: 01.04.2021).

5. Про вжиття заходів щодо забезпечення незалежності суддів та авторитету правосуддя за повідомленням заступника голови Московського районного суду міста Харкова Крівцова Д.А. : рішення Вищої ради правосуддя від 25.06.2020 р. № 1981/0/15-20. URL: https:/hcj.gov.ua/doc/doc/3549 (дата звернення: 06.04.2021).

6. Вирок Петрівського районного суду Кіровоградської області. Справа№ 1120/1562/12. URL : http://www.reyestr. court.gov.ua/Review/27937989 (дата звернення: 12.03.2021).

7. Про вжиття заходів щодо забезпечення незалежності суддів та авторитету правосуддя за повідомленням Голови Вищого антикорупційного суду Танасевич О.В. : рішення Вищої ради правосуддя від 08.10.2020 р. 


\section{Кримінальне право, кримінальний процес та криміналістика}

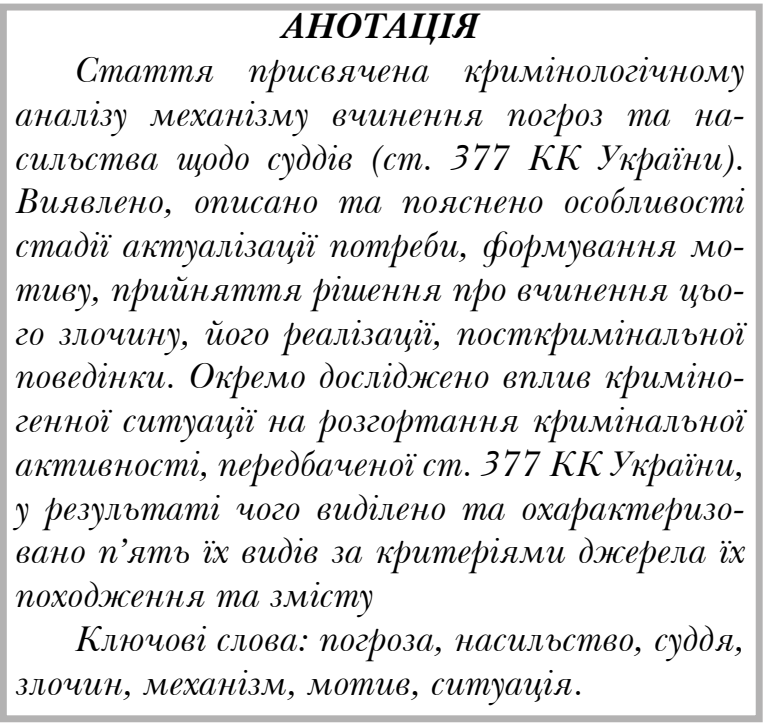

№ 2802/0/15-20. URL: https:/hcj.gov.ua/doc/ doc/4386 (дата звернення: 06.04.2021).

8. Правовий нігілізм: народний депутат I. Мосійчук та «активісти» дискредитують суд 2 : відеоматеріал / Відкритий суд. URL: http:// open-court.org/video/spicy/16718/ (дата звернення: 07.05.2021).

9. Про пробацію : Закон України від 05.02.2015 р. № 160-VIII. URL: https:// zakon.rada.gov.ua/laws/card/160-19 (дата звернення: 03.05.2021).

Larisa M. MARIENKO, graduate student (Kharkiv National University of Internal Affairs, Kharkiv, Ukraine)

PECULIARITY OF INDIVIDUAL CRIMINAL BEHAVIOR'S MECHANISM, PROVIDED BY ART. 377 OF CRIMINAL CODE OF UKRAINE: CRIMINOLOGICAL ANALYSIS

The article is devoted to the peculiarities of individual criminal behavior`s mechanism, provided for in Art. 377 of Criminal Code of Ukraine. It has been developed and found, that it is characterized by motives for security, selfaffirmation and revenge; most threats are made orally (94\%), personally, directly $(80 \%)$, before the announcement of the court decision (76\%) and has the purpose to influence the judge's decision, in $23 \%$ - revenge for the professional activities of the judge; physical violence in the form of light bodily injuries $(87,5 \%)$ in most cases is used in the territory adjacent to the judge's resi- dence $(40 \%)$ or in the courtroom $(30 \%)$ by striking with hands and feet.

Most threats are actions taken during or immediately after the sentencing in criminal proceedings during a court hearing, in the courtroom, and in places reserved for persons in custody. They are expressed orally, personally, directly ( $80 \%$ of cases). At the same time, investigative and judicial practice records other ways of expressing threats of violence by a judge: a) by telephone orally directly to a judge or other court employee; b) by SMS and messages on Internet pages (forums, chats, posts and comments under posts, etc.); c) by e-mail, postal correspondence, through the court office or to the home address of the judge; d) combined means and methods, using sms-messages, messages in messengers and personal threats; e) through implicit actions that are threatening to use violence (isolated cases).

Postcriminal behavior has been studied and three types of it has been identified: active-anticriminogenic, sequential-criminogenic, neutral-nihilistic. The most dangerous of them is sequential-criminogenic behavior (occurs in approximately $20 \%$ of cases), which occurs in the case of the deployment of a system of criminal activity by the so-called real criminological type of criminal, when the threat is supported by a firm real intention to implement it in a favorable environment (after release) from places of imprisonment, in a convenient place and at a convenient time, etc.). Such behavior is characterized by: a) active action of psychological protection mechanisms, maintaining the focus on self-justification, shifting the blame on others, including the victim, legitimizing previous and future criminal behavior; b) preservation of aggressive potential and high anxiety of the individual, which has the value of background determination (by the mechanism of manifestation of substitute aggression) for other, related criminal offenses not directly related to the genesis of the crime under Art. 377 of the Criminal Code of Ukraine.

The significance of criminogenic situations in the mechanism of threats or violence against a judge, lay judge, juror has been characterized, as a result of which five of their types has been identified, described and explained according to the criteria of their sources and content. 